

\title{
TEKNOLOGI PERTANIAN TERPADU BERBASIS FILOSOFI TRI HITA KARANA DALAM USAHATANI MENUJU PERTANIAN ORGANIK
}

\section{(Integrated Agriculture Technology Based on Tri Hita Karana Philoshopy toward Organic Agriculture)}

\author{
Ni Putu Sukanteri ${ }^{1}$, Pande Komang Suparyana ${ }^{1}$, I Made Suryana², I Made Dedy Setyawan ${ }^{3}$ \\ ${ }^{1}$ Program Studi Agribisnis Fakultas Pertanian Universitas Mahasaraswati \\ Kampus Universitas Mahasaraswati Denpasar Jl. Kamboja No 11 A Denpasar \\ ${ }^{2}$ Program Studi Agroteknologi Fakultas Pertanian Universitas Mahasaraswati \\ ${ }^{3}$ Sekolah Tinggi Ilmu Komputer Bali \\ Email: putusukanteri@unmas.ac.id
}

Diterima 24 Mei 2018, Disetujui 31 Oktober 2019

\begin{abstract}
ABSTRAK
Teknologi pertanian terpadu merupakan sebuah inovasi integrasi tanaman dengan ternak sapi. Penerapan adopsi teknologi usahatani kepada petani dilakukan untuk mengoptimalkan potensi daerah dengan pemanfaatan sumber daya lokal. Usahatani tanaman padi dibudidayakan secara organik melalui pemanfaatkan kompos dan biourine dari limbah ternak sapi, namun ketersediaan air hanya mengandalkan air hujan merupakan suatu kendala terbesar dalam produksi usahatani, sehingga perlu dilakukan perencanaan pola tanam komoditas pertanian pada lahan sawah tadah hujan. Tujuan penelitian untuk mengetahui keuntungan dan produktivitas usahatani selama menerapkan teknologi pertanian terpadu, mengetahui konsep penerapan filosofi Tri Hita Karana dalam usahatani di Kelompok Tani Suka Mandiri, Desa Megati Kecamatan Selemadeg Timur, Kabupaten Tabanan, Provinsi Bali. Hasil penelitian dalam bentuk data primer diperoleh melalui wawancara kepada responden, data selanjutnya ditabulasi dan dianalis menggunakan analisis keuntungan, analisis ratio dan persamaan efektifitas program. Keuntungan usahatani yang diperoleh dari usaha tani padi selama menerapkan inovasi teknologi pertanian terpadu sebesar Rp 6.796.430,00 dengan R/C ratio sebesar 2,22. Produktivitas usahatani padi diperoleh selama penerapan inovasi teknologi terpadu tanaman padi dengan ternak sapi diperoleh sebesar 7,6 ton/ha, dan efisiensi program adopsi teknologi sebesar 80\%. Penerapan Filosofi Tri Hita Karana dilakukan pada kelompok tani Suka Mandiri yaitu untuk menciptakan keharmonisan antara Tuhan, manusia dengan alam lingkungan. Konsep hubungan manusia dengan Tuhan dilaksanaan melalui ritual dalam usahatani, hubungan antar manusia dengan manusia untuk menciptakan keharmonisan antar petani selama pengelolaan usahatani. Hubungan manusia dengan alam dapat dilihat dengan penggunaan input organik dilahan pertanian dalam upaya perbaikan unsur hara tanah untuk mendapatkan hasil pertanian organik secara berkelanjutan
\end{abstract}

Kata Kunci: adopsi, teknologi, terpadu, organik

\begin{abstract}
Integrated agricultural technology is an innovation in the integration of crops with cattle. The adoption of farming technology adoption to farmers is carried out to optimize the potential of the area
\end{abstract}


by utilizing local resources. Rice farming is organically cultivated through the use of compost and biourine from cattle waste, but the availability of water only relies on rain water is the biggest obstacle in farming production, so it is necessary to plan the pattern of planting of agricultural commodities on rainfed lowland. The purpose of this study was to determine the benefits and productivity of farming during the implementation of integrated agricultural technology, to find out the concept of applying the philosophy of Tri Hita Karana in farming in the Suka Mandiri Farmer Group, Megati Village, Selemadeg Timur District, Tabanan Regency, Bali Province. The results of the study in the form of primary data were obtained through interviews with respondents, the data were then tabulated and analyzed using profit analysis, ratio analysis and equality of program effectiveness. Farming profits obtained from rice farming while implementing integrated agricultural technology innovation amounted to $R p$ 6,796,430.00 with an $R / C$ ratio of 2.22. The productivity of rice farming obtained during the application of integrated technological innovations in rice plants with cattle was obtained at 7.6 tons / $h a$, and the efficiency of the technology adoption program was $80 \%$. The application of the Tri Hita Karana philosophy is carried out at the Suka Mandiri farmer group to create harmony between God, humans and the natural environment. The concept of human relations with God is carried out through rituals in farming, the relationship between humans and humans to create harmony between farmers during farm management. The relationship between humans and nature can be seen by the use of organic inputs on agricultural land in an effort to improve soil nutrients to produce organic agricultural products in a sustainable manner.

Keywords: adoption, technology, tntegrated, organic

\section{PENDAHULUAN}

Sektor pertanian merupakan salah satu sektor utama sebagai penghasil pangan. Pertanian menjadi sangat penting karena mempunyai kontribusi dalam pencapaian tujuan pembangunan perekonomian nasional karena Indonesia merupakan negara agraris yang sebagian besar masyarakat Indonesia adalah petani. Sektor pertanian masih memegang peranan penting karena sektor pertanian memberikan kontribusi terhadap kehidupan masyarakat dan keberlanjutan pangan suatu bangsa, sektor pertanian menciptakan lapangan kerja yang tinggi dalam penyerapan angkatan kerja, selain itu sektor pertanian mampu menyediakan keragaman pangan sehingga sektor pertanian mempengaruhi konsumsi dan gizi masyarakat. Sektor pertanian di Bali menurut Badan Pusat Statistik Provinsi Bali (2017) menunjukkan bahwa Kabupaten Tabanan merupakan jumlah produksi padi terbesar di Bali dalam kurun waktu 2013 sampai dengan 2016.

Jumlah produksi padi di Kabupaten Tabanan sejak lima tahun terakhir berdasarkan data Badan Pusat Statistik Provinsi Bali tahun 2017 yaitu tahun 20014 sebesar 214.203 ton, produksi padi tahun 2013 sebesar 233.681 ton, produksi padi tahun 2012 sebesar 222.706 ton. Produksi padi tahun 2011 di Kabupaten Tabanan sebesar 210.762 dan produksi padi di tahun 2010 sebesar 223.256 (BPS, 2017). Jumlah produksi padi menunjukkan fluktuasi produksi disebabkan masalah yang timbul selama kurun waktu tersebut. Adapun masalah yang di hadapi antara lain alih fungsi lahan, banyaknya tenaga kerja pertanian beralih ke pekerjaan lain, kualitas tenaga kerja pertanian tidak memadai, persediaan lahan yang semakin sempit. Masalah lain yang dihadapi oleh petani dalam produksi pertanian meliputi masalah faktor produksi usahatani meliputi, semakin mahalnya angkos tenaga kerja pertanian, mahalnya alat-alat penunjang kerja pertanian seperti traktor dan mesin pencukur rumput. Ketersediaan air untuk lahan pertanian sangat terbatas. Kondisi tersebut menyebabkan petani mengalami kesulitan dalam meningkatan produksinya, sehingga hasil yang diperoleh hanya sesuai modal yang dimiliki petani.

Untuk merangsang petani dalam meningkatkan hasil produksi pertanian berbagai bentuk bantuan dan pelatihan telah dilakukan oleh pemerintah khususnya di 
Provinsi Bali, pemerintah telah memberikan bantuan berupa upaya khusus yang dilakukan untuk pengembangan padi dan jagung. Agar sasaran pembangunan pertanian mampu memberikan kontribusi yang nyata maka pemerintah telah memberikan berbagai bantuan untuk merangsang agar petani mempunyai inovasi yang tinggi dalam menciptakan produksi yang baik, dalam upaya meningkatkan produksi pertanian pemerintah provinsi Bali telah memberikan bantuan peningkatan produksi pertanian di Desa Megati melalui sistem pertanian terintegrasi tahun 2014. Teknologi Integrasi Pertanian adalah upaya terobosan dalam mempercepat adopsi teknologi pertanian kepada masyarakat perdesaan. Teknologi mengintegrasikan kegiatan sektor pertanian dengan sektor pendukungnya, baik secara vertikal maupun horizontal, sesuai dengan potensi setiap wilayah dengan mengoptimalkan pemanfaatan sumber daya lokal yang ada. Kegiatan utama adalah mengintegrasikan usaha budi daya tanaman dengan ternak sapi, yaitu limbah tanaman diolah untuk pakan bermutu (makanan ternak), cadangan pakan pada musim kemarau dan limbah ternak (faeces, urine) diolah menjadi biogas, pupuk organik (Wisnuardhana, 2011).

Tujuan penelitian yaitu untuk mengetahui keuntungan usahatani dan efektifitas program pertanian terpadu yang dilakukan pada Kelompok Tani Suka Mandiri, serta mengetahui konsep penerapan filosofi Tri Hita Karana dalam usahatani sebagai salah satu upaya menciptakan keharmonisan antara manusia, alam dan lingkungan dalam mendukung pertanian organik yang berkelajutan.

Kelompok Tani Suka Mandiri merupakan salah satu kelompok tani berlokasi di Kecamatan Selemadeg Timur, Kabupaten Tabanan, dengan anggota 21 orang. Kondisi lahan pertanian tergolong sawah tadah hujan merupakan suatu kendala yang besar dalam produksi usahatani sehingga perlu dilakukan perencanaan dalam penanaman komoditas pertanian. Sehingga perlu diketahui keuntungan usahatani selama menerapkan inovasi teknologi pertanian terpadu, serta penerapan filosofi Tri Hita Karana dalam pengelolaan usahatani dalam upaya mengetahui produktifitas penggunaan sumberdaya pertanian pada usahatani kelompok tani suka mandiri dalam satu kali periode produksi.

\section{METODEPENELITIAN}

Penelitian tentang aplikasi teknologi integrasi pertanian berbasis sumber daya lokal dengan mempertahankan filosofi Tri Hita Karana dalam upaya mewujudkan pertanian organik dilakukan di Kelompok Tani Suka Mandiri, Desa Megati Kecamatan Selemadeg Timur, Kabupaten Tabanan, Provinsi Bali. Penelitian dilakukan karena Kelompok Tani Suka Mandiri merupakan kelompok yang berada pada kawasan lahan sawah tadah hujan yang telah menerapkan teknologi integrasi pertanian selama lima tahun dengan mempertahankan konsep filoshofi Tri Hita Karana diterapkan sepanjang tahun dan mempertahankan kalender tanam berdasarkan wariga di lahan pertanian yang dipercaya dapat menjamin petani panen dengan baik.

Data primer diperoleh dari hasil wawancara dengan responden kelompok Tani Suka Mandiri yang telah panen di bulan April 2019. Populasi dalam penelitian yaitu petani yang menjadi anggota Kelompok Tani Suka Mandiri berjulmah 21 orang. Jumlah sampel diambil secara sensus dimana seluruh populasi dijadikan sampel dalam penelitian ini yaitu sebanyak 21 petani.

\section{Metode Analisis Data \\ a. Analisis Keuntungan}

Keuntungan dapat diformulasikan sebagai berikut (Soekartawi, 2011):

$$
\mathrm{Kt}=\operatorname{PrT}-\mathrm{B}
$$

Karena PrT adalah produksi total dikalikan harga dan biaya produksi adalah banyaknya input dikalikan harganya sehingga persamaannya dapat ditulis. 


$$
\mathrm{Kt}=\mathrm{Py} . \mathrm{Y}-\left(\mathrm{Px}_{1}+\mathrm{Px}_{2}+\ldots \mathrm{Px}_{\mathrm{n}}\right)
$$

Dimana

Py $\quad=$ Harga produksi

$\mathrm{Y}=$ Jumlah Produksi

Px = Harga input produksi

$\mathrm{Px}_{1} \ldots \mathrm{n}=$ harga input $\mathrm{X}_{1}$

$\mathrm{X}_{1} \quad=$ jumlah input

$\mathrm{Kt}=$ Keuntungan

\section{b. Analisis Ratio}

Pendapatan usahatani pada Kelompok Tani Suka Mandiri diperoleh dari total penerimaan dikurangi dengan total biaya dalam suatu proses produksi. Sedangkan total penerimaan dari produksi dikalikan dengan harga produksi. Untuk mencari pendapatan dalam perhitunang menggunakan cash flow. In flow atau penerimaan dan out flow atau biaya produksi.

Pendapatan $=$ in flow $($ Penerimaan $)-$ out

flow (Biaya Produksi) (Panjaitan et al, 2014)

\section{c. $\mathrm{R} / \mathrm{C}$ ratio}

$\mathrm{R} / \mathrm{C}$ ratio adalah perbandingan antara total penerimaan dengan total biaya (Panjaitan et al., 2014).

Apabila :

$\mathrm{R} / \mathrm{C}$ ratio $<1$ artinya usaha tani belum mendapatkan keuntungan

$\mathrm{R} / \mathrm{C}$ ratio $=1$ artinya usahatani tidak mendapat keuntungan dan tidak mengalami kerugian

$\mathrm{R} / \mathrm{C}$ ratio $>1$ artinya usahatani memberikan keuntungan

\section{d. Efektivitas penerapan teknologi integrasi pertanian}

Efektivitas merupakan ukuran yang menggambarkan sejauhmana sasaran dapat dicapai. Tujuannya untuk meningkatkan produktivitas padi lebih dari 0,3 ton/hektar. Persamaan untuk mengukur efektivitas dalam pencapaian tujuan program integrasi tanaman padi dengan ternak sapi.

$$
\text { Efektivitas Program }=\frac{R}{T} \times 100 \%
$$

Dimana:

$\mathrm{R}=$ Realita produktivitas padi (ton)

$\mathrm{T}=$ Target produktivitas padi (ton)

Untuk mengukur efektivitas usahatani padi dalam meningkatkan produktivitas padi lebih besar dari 0,3 ton/hektar digunakan standar acuan yang ditetapkan oleh Litbang

Tabel 1. Standar Acuan Pengukuran Efektivitas Produktivitas Padi

\begin{tabular}{cc}
\hline Rasio Efektivitas (\%) & Tingkat Capaian \\
\hline Di bawah 40 & Sangat tidak efektif \\
$40-59,99$ & Tidak efektif \\
$60-79,99$ & Cukup efektif \\
Di atas 80 & Sangat efektif \\
\hline
\end{tabular}

Sumber: Budiani 2009).

Depdagri (Budiani, 2009). Adapun standar acuan untuk mengukur efektivitas dapat dilihat pada Tabel 1 .

\section{HASIL DAN PEMBAHASAN}

\section{Karekteristik Anggota Kelompok Tani Suka Mandiri}

Karakteristik anggota kelompok tani meliputi usia petani, pendidikan petani, luas lahan garapan yang dikelola oleh anggota Kelompok Tani Suka Mandiri. Adapun karakteristik anggota kelompok tani dapat dilihat di bawah ini. Berdasarkan hasil penelitian pada Kelompok Tani Suka Mandiri diperoleh bahwa usia petani tergolong produktif, sebesar 90,48\% usia petani berada pada usia antara 15 sampai 60 tahun. Anggota kelompok tani berada pada usia diatas 60 tahun sebesar 9,52\% yaitu petani berada pada usia non produktif. Hal ini menunjukkan bahwa pada usia produktif kemungkinan besar seseorang dapat bekerja dengan baik dan maksimal dan mampu bekerja dengan baik serta maksimal dalam mengadopsi teknologi pertanian.

Tingkat pendidikan formal yang dimiliki petani akan menunjukan tingkat pengetahuan serta wawasan dalam menerapkan apa yang diperolehnya dalam upaya meningkatkan usahataninya. Pendidikan yang dimiliki oleh patani daya serap terhadap inovasi. Tingkat 
pendidikan seseorang yang pada umumnya menunjukkan daya kreatifitas manusia dalam berfikir dan bertindak. Hasil penelitian menujukkan bahwa terdapat $28,57 \%$ petani yang berpendidikan menengah atas, terdapat $23,81 \%$ petani yang menempuh pendidikan menengah pertama, dan jumlah tertinggi yaitu sebesar 38,10 persen petani menempuh pendidikan dasar, sedangkan jumlah petani yang menempuh pendidikan setingkat diploma sebesar 9,52\%. Hasil penelitian ini menunjukkan bahwa petani di Kelompok Tani Suka Mandiri tergolong mempunyai pendidikian yang rendah.

\section{Luas Lahan Garapan Anggota Kelompok Tani Suka Mandiri}

Hasil penelitian menunjukkan bahwa petani yang mempunyai luas lahan garapan rendah sebesar 4,76\%, petani yang mempunyai luas lahan garapan sedang sebesar $85,71 \%$ dan sebesar $9,52 \%$ petani

Tabel 2. Luas lahan Garapan anggota Kelompok Tani Suka Mandiri

\begin{tabular}{cccc}
\hline & Luas Lahan & \multicolumn{2}{c}{ Jumlah } \\
No & Garapan & Orang & Persentase \\
\hline 1 & $<0,25 \mathrm{Ha}$ & 1 & 4,76 \\
2 & $0,25-1 \mathrm{Ha}$ & 18 & 85,71 \\
3 & $>1 \mathrm{Ha}$ & 2 & 9,52 \\
\hline \multicolumn{2}{c}{ Jumlah } & 21 & 100,00 \\
\hline
\end{tabular}

mempunyai luas lahan garapan sebesar 9,52 hektar. Kepemilikan luas garapan dapat dilihat pada Tabel 2.

Berdasarkan hasil penelitian pada petani anggota Kelompok Suka Mandiri menunjukkan bahwa terdapat $85,71 \%$ lebih lahan garapan responden termasuk kepemilikan lahan sedang. Semakin tinggi lahan yang dimiliki maka semakin besar peluang produksi yang mampu dihasilkan pada lahan tersebut.

\section{Keuntungan Usahatani dan Besarnya Rasio Usahatani $(\mathrm{R} / \mathrm{C})$}

Keuntungan usahatani padi dengan menerapkan teknologi integrasi pertanian berbasis pemanfaatan sumberdaya alam diperoleh dengan mengurangkan penerimaan dengan biaya usahatani yang dikeluarkan selama satu kali periode usahatani padi. Waktu yang diperlukan untuk memperoleh panen padi berada pada kisaran waktu empat bulan. Biaya yang diperlukan selama pengelolaan padi meliputi biaya yang diperlukan untuk input produksi usahatani, sedangkan penerimaan hanya diperoleh dengan menjual hasil panen padi selama periode tersebut. Hasil penelitian dapat diperoleh bahwa keuntungan usahatani kelompok tani Suka Mandiri sebesar $\mathrm{Rp}$ 6.925.430. dengan penerimaan sebesar Rp12.361.000 di atas luas rata-rata luas lahan

Tabel 3. Keuntungan usahatani pada kelompok tani Suka Mandiri

\begin{tabular}{llcc}
\hline No & Keuntungan & $\begin{array}{c}\text { Jumlah } \\
(\mathrm{Rp})\end{array}$ & Rasio R/C \\
\hline & Total & & \\
1 & Penerimaan & 12.361 .000 & 2,22 \\
2 & Total Biaya & 5.564 .570 & \\
\hline & Jumlah & 6.925 .430 & \\
\hline
\end{tabular}

0,37 ha. Biaya yang dibutuhkan selama satu kali periode produksi padi sebesar Rp 5.564.570.

Tabel 3 menunjukkan bahwa ratio $(\mathrm{R} / \mathrm{C})$ merupakan perbandingan antara total penerimaan dengan total biaya, pada Kelompok Tani Suka Mandiri diperoleh bahwa $\mathrm{R} / \mathrm{C}$ ratio sebesar 2,22 . Besaran ratio ini mengindikasikan setiap 100 rupiah yang dikeluarkan dalam suatu awal kegiatan usahatani akan memperoleh penerimaan sebesar Rp 222 pada akhir kegiatan usahatani dengan menerapkan teknologi integrasi berbasis sumberdaya pertanian antara tanaman padi dengan ternak sapi. Hal ini menunjukkan bahwa semakin besar nilai ratio maka semakin besar pula keuntungan dalam melaksanakan usahatani dengan mengalokasikan sumberdaya secara optimal.

Penerapan filosofi Tri Hita Karana pada 


\section{pengelolaan usahatani padi}

Nilai budaya tradisional (local Genius) merupakan suatu keunikan lokal yang dimiliki oleh subak, yang dapat dilihat dari pelaksanaan upacara yang dilakukan petani setiap mulai beraktifitas di lahan sawah. Upacara yang dilakukan merupakan kepercayaan yang dilakukan secara turun temurun dengan keyakin yang dianut bahwa dengan pelaksanaan upacara selama proses usahatani diharapkan dapat memberikan berkah panen yang optimal. Apalagi dijalankan dengan teknologi dan konsistensi oleh petani dengan baik pula.

Eksistensi pelaksanaan upacara dari mulai mengolah tanah hingga panen berakhir merupakan salah satu pengejawantahan penerapan filosofi Tri Hita Karana yaitu hubungan antara manusia dengan Tuhan Yang Maha Esa, sebagai ungkapan rasa syukur dan bakti kepada Tuhan yang Maha Esa,

Kegiatan upacara atau ritual dalam subak, berbagai jenis upacara keagamaan dilaksanakan di tempat sucii atau tempat pemujaan baik milik bersama atau milik perorangan. Beragam upacara keagamaan baik yang dilakukan secara kolektif maupun perseorangan bervariasi antara subak.

Bentuk upacara yang merupakan ungkapan khusus dalam filosofi Tri Hita Karana yang ditujukan untuk menciptakan keharmonisan dengan Pencipta atau parhyangan dan dilaksanakan mulai mengolah tanah hingga panen di lahan sawah dapat dilihat pada Tabel 4.

Penerapan konsep Tri Hita Karana dalam usahatani yang kedua yaitu hubungan manusia dengan manusia, Filosofi hubungan antara manausia dengan manusia yang dilakukan dalam Kelompok Tani Suka Mandiri terlihat selama pengelolaan pertanian yang tujuannya agar tercipta hubungan yang harmonis antara sesama anggota kelompok atau sesama petani dalam mewujudkan panen yang diinginkan. Pelaksanaan rapat anggota Kelompok Tani Suka Mandiri dalam Subak dalam mendiskusikan kegiatan usahatani mulai dari mengolah tanah, mulai penanaman komoditas yang dipilih dan pengaturan pengairan dilakukan secara periodik. Filosofi

Tabel 4. Kegiatan Ritual yang dilakukan oleh petani sebagai bentuk penerapan Tri Hita Karana dalam hubungan Manusia dengan Tuhan

\begin{tabular}{|c|c|c|c|c|}
\hline No & $\begin{array}{l}\text { Ritual dalam } \\
\text { usahatani }\end{array}$ & Jenis Ritual & Waktu Pelaksanaan & Sarana Upakara \\
\hline 1 & Magpag Toyo & $\begin{array}{l}\text { Mulai mengalirkan } \\
\text { air ke lahan sawah }\end{array}$ & $\begin{array}{l}\text { Sebelum mulai mengolah } \\
\text { lahan yang akan disalurkan ke } \\
\text { areal sawah setiap anggota } \\
\text { subak }\end{array}$ & $\begin{array}{l}\text { Banten: Wangi, Peras pejati, } \\
\text { dilaksanakan di ulun subak } \\
\text { dipersembahkan kepada Dewa Wisnu }\end{array}$ \\
\hline 2 & Mewinih & $\begin{array}{l}\text { Memulai membuat } \\
\text { bibit }\end{array}$ & $\begin{array}{l}\text { Pada saat mulai menebarkan } \\
\text { bibit di sawah }\end{array}$ & Peras Daksina di sanggah luan, \\
\hline 3 & $\begin{array}{l}\text { Mulai mengolah } \\
\text { tanah }\end{array}$ & & & $\begin{array}{l}\text { Tipat Daksina di sedahan carik } \\
\text { sebagai pengawit mulai mengolah } \\
\text { tanah }\end{array}$ \\
\hline 4 & $\begin{array}{l}\text { Nandur/ } \\
\text { Pemiwit }\end{array}$ & $\begin{array}{l}\text { Ritual yang } \\
\text { dilakukan saat } \\
\text { memulaii menanam } \\
\text { padi di lahan yang } \\
\text { pertama }\end{array}$ & Mulai menanam Padi & $\begin{array}{l}\text { Pejati di pura Bedugul } \\
\text { Tipat daksina di sanggah luan }\end{array}$ \\
\hline 5 & $\begin{array}{l}\text { Tutug } \\
\text { Kambuhan }\end{array}$ & $\begin{array}{l}\text { Ritual perayaaan } \\
\text { setelah } 42 \text { hari masa } \\
\text { tanam }\end{array}$ & $\begin{array}{l}\text { Hari ke } 42 \text { setelah menanam } \\
\text { padi }\end{array}$ & Tipat daksina, wangi, dan rayunan \\
\hline 6 & Mebiukukung & Umur padi tiga bulan & & Banten biukukung \\
\hline 7 & Purnama Tilem & & & Wangi raka \\
\hline 8 & Manyi & Setelah mulai panen & 4 bulan & $\begin{array}{l}\text { Membuat simbul dewi Sri dari padi } \\
\text { disertai banten upacara }\end{array}$ \\
\hline
\end{tabular}


Tri Hita Karana ini juga dilakukan dengan harapan seluruh kegiatan pertanian berjalan dengan harmonis dapat menekan konflik yang terjadi dianatara sesama manusia. Ada pun penerapan filosofi trihita katana dalam hubungannya dengan manusia yang dilakukan pada kelompok Suka Mandiri yaitu segala kegiatan yang akan dilakukan diawali dengan musyawarah atau rapat kelompok, musyawarah menentukan kapan mulai mengolah tanah, kapan penentuan mulai menanam padi bahkan kapan melaksanakan kerja gotong royong pembersihan saluran air di areal persawahan.

Filosofi Tri Hita Karana yang ketiga yaitu hubungan manusia dengan alam merupakan salah satu bentuk bukti nyata yang dilakukan petani dalam menjaga keseimbangan alam. Filosofi ini dilakukan oleh petani secara nyata meliputi mengurangi penggunaan pestisida, menggunakan pupuk organik yang diolah dari kotoran ternak sapi yang meraka pelihara sendiri. Tidak menggunakan pengairan pada waktu tertentu. Melaksanakan hari nyepi untuk menggembalikan suasana di lahan sawah menjadi hening merupakan upaya mengembalikan keharmonisan alam semesta dan menciptakan pertanian organik secara bertahap.

\section{Efektifitas Usahatani padi dengan penerapan teknologi integrasi pertanian.}

Produktivitas usahatani yang dihasilkan melalui penerapkan teknologi integrasi pertanian antara tanaman padi dengan ternak sapi pada usahatani Kelompok Tani Suka Mandiri yang dilakukan menunjukkan produksi tanaman padi pada lahan sawah tadah hujan. Tujuan penerapan teknologi integrasi pertanian yang mengoptimalkan sumber daya yang ada yaitu mengolah limbah ternak dijadikan input dalam pertanian dan mengolah limbah pertanian untuk dijadikan pakan. Untuk mengukur efektivitas usahatani padi pada usahatani Kelompok Tani Suka Mandiri dalam meningkatkan produktivitas padi minimal sebesar 0,3 ton/hektar dihitung dari target standar produktivitas padi sebesar 5 ton per hektar, digunakan standar acuan
Tabel 5. Standar Acuan Pengukuran Efektivitas Produktivitas Padi

\begin{tabular}{cc}
\hline Rasio Efektivitas (\%) & Tingkat Capaian \\
\hline Di bawah 40 & Sangat tidak efektif \\
$40-59,99$ & Tidak efektif \\
$60-79,99$ & Cukup efektif \\
Di atas 80 & Sangat efektif \\
\hline
\end{tabular}

Sumber: Budiani, 2009.

yang ditetapkan oleh Litbang Depdagri (Dewi et al, 2012). Adapun standar acuan untuk mengukur efektivitas dapat dilihat pada Tabel 5.

Jenis tanaman padi yang ditanam oleh petani secara serentak yaitu padi jenis Ciherang, berdasarkan hasil penelitian menunjukkan bahwa produktivitas rata-rata hasil panen pada kelompok tani Suka Mandiri yaitu lima ton/hektar sebelum dilaksanakan program inovasi teknologi pertanian terintegrasi antara tanaman dengan ternak sapi. Dengan adanya penerapan teknologi pertanian diharapakan produktivitas usahatani meningkat melebihi target produktivitas minimal pada acuan Litbang Depdagri, sehingga target produktivitas dapat dilihat sebagai berikut:

Target: 5 ton/hektar $+0,3$ ton $/$ hektar $=5,3$ ton/hektar

Hasil penelitian yang telah dilakukan pada usahatani padi dengan produktivitas rata-rata hasil panen padi setelah penerapan integrasi pertanian antara tanaman padi dengan ternak sapi pada Kelompok Tani Suka Mandiri sebesar 7,6 ton/hektar. Perolehan ini tergolong lebih tinggi jika dibandingkan dengan produktivitas usatani padi pada kelompok tani di daerah lain yang merepakan program integrase pertanian. Penilaian efektivitas program integrasi pertanian dalam upaya meningkatkan produktivitas padi pada Kelompok Tani Suka Mandiri dapat diketahui dengan metode sebagai berikut.

$$
\begin{aligned}
\text { Efektivitas Program } & =\frac{5,3 \text { ton } / \text { ha }}{7,6 \text { ton } / \text { ha }} \times 100 \% \\
& =143,39 \%
\end{aligned}
$$


Nilai efektivitas yang dihasilkan dengan mengukur teknologi integrasi pertanian agar memperoleh peningkatan produktivitas padi lebih besar dari 0,3 ton/hektar yaitu 143,39\%, yang memiliki nilai $>80 \%$ menunjukkan teknologi integrasi pertanian yang diterapkan pada Kelompok Tani Suka Mandiri terlaksana secara sangat efektif dalam upaya meningkatkan produktivitas usahatani padi.

\section{KESIMPULAN DAN SARAN}

Berdasarkan hasil pembahasan dari penelitian yang telah dilakukan pada Kelompok Tani Suka Mandiri yang telah menerapkan sistem pertanian terintegrasi sejak tahun 2014 dapat disimpulkan bahwa : Keuntungan usahatani yang diperoleh dari usaha tani padi selama menerapkan inovasi teknologi integrasi pertanian pada Kelompok Tani Suka Mandiri sebesar Rp 6.796.430,00 dengan $\mathrm{R} / \mathrm{C}$ ratio sebesar 2,22. Nilai efektivitas program pertanian terintegrasi dalam upaya peningkatan produktivitas padi sebesar 143,39\%. Penerapan Filosofi Tri Hita Karana dilakukan untuk menciptakan keharmonisan antara Tuhan, manusia dengan alam lingkungan dalam upaya menciptakan hasil pertanian organik yang berkelanjutan.

\section{Saran}

Saran bagi petani terus melaksanakan usahataninya dengan baik untuk mendapatkan pendapatan untuk keluarganya. Untuk mengatasi kesulitan produksi pada musim kemarau bisa dilakukan penanaman jenis tanaman berumur pendek yang memerlukan air dengan volume lebih sedikit. Petani disarankan terus menggunakan pupuk organik padat maupun cair agar di tahun mendatang bisa menghasilkan produk organik.

\section{DAFTAR PUSTAKA}

BPS. 2017. Badan Pusat. https://bali.bps.go. id/statictable/2014/11/06/26/luas-panenrata-rata-produksi-dan-produksi-padisawah-dan-padi-ladang-menurut- kabupaten-kota-di-bali-sensus-

pertanian-2013.html. Badan Pusat Statistik. Provinsi Bali. Diakses tanggal 5 September 2019.

Chintya. 2012. Analisis Efisiensi Usahatani Padi Sawah. [E-journal] Agribisnis dan Agrowisata. 1(1). Fakultas Pertanian Universitas Udayana. Denpasar. Tersedia: http:// download. portalgaruda. org /article .php ? article $=16306 \&$ val $=$ 992. Diakses tanggal 19 Agustus 2015.

Dewi, I. G. A. C., Suamba, I. K., \& Ambarawati I, I. G. A. 2012. Analisis Efisiensi Usahatani Padi Sawah. Journal Agribisnis dan Agrowisata. 1(1). ISSN 2685-3809 Tahun 2012

Kementan. 2015. Peraturan Menteri Pertanian Nomor 03/Permentan/ 0T.140/ 2/2015. Menteri Pertanian. Republik Indonesia. Tersedia: http:// bkppp. bantulkab.go.id /filestorage/ dokumen/ 2015/03/ Permentan \%20 Nomor\% 2003-2015 \%20Pedoman\% 20Upsus\% 20pajale.pdf. Diakses tanggal 6 November 2015.

Mubyarto. 1977. Pengantar Ekonomi Pertanian. Lembaga Penelitian Pendidikan dan Penerangan Ekonomi dan Sosial. Jakarta Barat.

Nurhasikin. 2013. Penduduk Usia Produktif dan Ketenagakerjaan. [Artikel on-line] Badan Kependudukan dan Keluarga Berencana Nasional. Provinsi Riau. Tersedia: http:// kepri.bkkbn.go.id/ Lists/Artikel/DispForm.aspx?ID $=144$. Diakses tanggal 12 Desember 2015.

Soekartawi. 2011. Ilmu Usahatani dan Penelitian untuk Pengembangan Petani Kecil. UI Press, Jakarta.

Suryana, S. 2007. Analisis Faktor-faktor yang Mempengaruhi Produksi Jagung di Kabupaten Blora. [Tesis Online] Magister Ilmu Ekonomi dan Pembangunan Universitas Diponegoro. Semarang. Tersedia: http:// eprints 
.undip.ac.id/18736/1/Sawa_Suryana.pdf Diakses tanggal 19 Juli 2015.

Wisnuardhana, I. B. 2011. Petunjuk Teknis

Simantri. Kementrian Pertanian Provinsi

Bali. Hal 10-20. Denpasar. 